\title{
BIOÉTICA E MEIO AMBIENTE: IMPLICAÇÕES PARA UMA ÉTICA DA LIBERTAÇÃO
}

César Augusto Costa ${ }^{1}$

RESUMO: O presente artigo aborda a relação entre bioética e o meio ambiente a partir das relações sociais. Para tal fim, se utilizamos das premissas no debate partindo dos conceitos cosmológicos; da revisão histórica do conceito da bioética; da Ecologia Profunda de Arne Ness, seguindo aos desdobramentos da tomada de consciência ambiental no movimento ecológico mundial e das contribuições da ética da libertação e da ética do desenvolvimento em face da questão ambiental.

Palavras-chave: Bioética; Ecologia Social; Ética Libertadora; Meio Ambiente.

\section{INTRODUÇÃO}

O Planeta Terra vive um período de intensas transformações técnicocientíficas, em contrapartida, das atuais engendram fenômenos de desequilíbrios ecológicos, que, se não forem remediados, ameaçam a vida (GUATARRI, 2001). Aludimos também que o problema ambiental é uma questão urgente visto na margem das presentes discussões teóricas das sociedades (CASTELLS, 1975). Além reimaginar o universo em constante processo de cosmogênese, estamos começando a entender a

\footnotetext{
${ }^{1}$ Doutorando em Educação Ambiental/FURG. Membro do Laboratório de Investigações em Educação, Ambiente e Sociedade/LIEAS-UFRJ. Bolsista do CNPq-Brasil. E-mail: csc193@hotmail.com
} 
responsabilidade dos homens pelos danos que causam ao ambiente a partir da indústria moderna. Temos lucidez de que a ecologia não é apenas um tema qualquer, é sob a ótica da bioética que podemos fecundar o debate, porque a crise ecológica gera consciência de que os seres humanos fazem parte do ambiente e que a luta pela justiça exige também uma luta ecológica (OLIVEIRA, 1998).

Não é possível pensar a questão ecológica isolada; ela precisa ser refletida com o problema da ecologia social (GUATARRI, 2001, BOFF, 1996), e com as demais instâncias sociopolíticas, humanistas e bioéticas. A crise ambiental resulta de nossa incapacidade de perceber os fenômenos de maneira integrada e de, justificar práticas predatórias através de conceitos equivocados. Pensar de modo integrado significa re-ligar as diversas dimensões da vida, propondo sistematicamente os problemas que nos afetam (HINRICHSEN, 2010). Como pensar as questões econômicas e sociais, éticas e ecológicas separadamente? È possível? Cremos constituir um desafio constante, haja vista que estamos condicionados a trabalhar em âmbitos fechados e despreparados para pensar sistematicamente 0 ambiente (DUVOISIN, 2002; MORIN, 2007).

Sendo assim, o problema é de mentalidade e ações onde temos que pensar numa antropologia mais justa para com o ambiente e também um ambiente mais ternário para com a sociedade (COSTA, 2004), partilhando à inversão de valores degradantes para compreendermos que rumos iremos viabilizar para a ecologia, sendo de suma importância a inter-relação com a bioética no debate atual.

\section{A ECOLOGIA: ENFOQUE COSMOLÓGICO}

A historicidade não é uma característica dos seres humanos, nem a natureza é um relógio que já aparece montado uma vez por todas. A natureza deriva de um processo cósmico: a cosmogênese (BOFF, 1996). Todos os seres vivos que entram na constituição de um sistema com seus seres humanos possuem sua latência e, em seguida, sua emergência. Sendo assim, são históricos, e todos os processos pressupõem uma fundamental irreversibilidade própria do tempo histórico. Segundo Boff (1996, p 43-44):

\footnotetext{
Prigogine mostrou que os sistemas abertos e a natureza são sistemas abertos, põe em xeque o conceito clássico do tempo linear postulado pela física. O tempo não é mais um parâmetro do movimento, mas a medida dos desenvolvimentos internos de um mundo em processo permanente de mudança, de passagem do desequilíbrio para patamares mais altos de equilíbrio.
}

A natureza se apresenta como um processo de autotranscendência e abre a possibilidade para um novo diálogo entre a visão eco-cosmológica e a teológica, pois essa transcendência pode apontar para o que as religiões Revbea, Rio Grande, V. 8, № 2:31-46, 2013. 
sempre chamaram de Deus. Com isso se mostra irreal a separação entre natureza e histórica, separação que legitimou e consolidou tantos dualismos. Como todos os humanos, a sua inteligibilidade e capacidade de comunicação e socialização resultam de um processo cósmico. Essa inclusão do ser humano no conjunto dos seres e como resultado de um processo cosmogênico impede a persistência do antropocentrismo; afirma que o sentido da evolução e existência consiste na produção do ser humano, homem e mulher. Pois o Universo se faz cúmplice do ser humano, não apenas dele, mas dos outros seres também. Para Boff,

\begin{abstract}
Pertencemo-nos mutuamente: os elementos primordiais do universo e do Big-Bang, os demais fatores constituintes do cosmos e nós mesmos como uma espécie que irrompeu tardiamente na evolução. Sem o global envolvimento de todos, não há evolução no universo. A partir disso devemos pensar cosmocentricamente e a agir ecocentricamente. Quer dizer na cumplicidade do universo inteiro (BOFF, 1996, p.45).
\end{abstract}

ser humano funda, assim, um ponto de referência, cuja função é cognitiva e revela a sua singularidade que não leva a romper com os demais seres, mas à sua união com eles, porque seus princípios de inter-relação estão primeiro no universo, e somente porque está nele pode emergir na Terra, progressivamente, nos vários seres complexos e, finalmente, nos filhos da Terra, que são os humanos.

Para aprofundarmos melhor esta reflexão, passemos à tomada da consciência ambiental e a visão da Ecologia Profunda de Ness.

\title{
A CONSCIÊNCIA AMBIENTAL
}

A tomada de consciência ecológica marcou os anos 70: podemos considerar a década, mais precisamente o ano de 1972 como simbólico, onde pode ter visto a publicação do relatório Meadows, a cargo do Clube de Roma, o qual situou sua dimensão planetária (MAZAUDOUX, 2009). A rápida disseminação da consciência ambiental relativa às poluições e à degradação desencadeou a implementar dispositivos técnicos que buscavam atenuar esse processo. É inclusive, graças a este contexto que consciência mundial que também o Direito Internacional do Meio Ambiente pode ter um desenvolvimento importante e eficaz no exame dos problemas.

Além disso, aliado a estes fatores, o papel da opinião pública desempenha centralidade na fiscalização e aplicação das regras estabelecidas. O papel das Associações ambientais e movimentos na aplicação do direito ambiental não derivaram de dúvidas, tanto no plano nacional quando no internacional.

Sendo assim, a atitude não foi diferente no século XIX, quando as Revbea, Rio Grande, V. 8, N²:31-46, 2013. 
Ligas e as Associações exerciam pressões sobre os governos para supressão do tráfico de escravos, para fazer respeitar a liberdade de credo ou para se insurgir contra violências em certos países (MAZAUDOUX, 2009). Tais movimentos da opinião pública só se tornaram universais nesta área, chamada de "proteção internacional dos Direitos Humanos", após a Segunda Guerra Mundial. Podemos esperar que o sistema teórico desenvolvido na questão ambiental possa se estender e, pelo menos por meio da integração, o conjunto das atividades humanas.

Um ponto de resposta reside numa proposição realizada, há alguns anos, pela França, no tocante a uma Organização Mundial para o meio ambiente, que, mesmo não sendo uma panacéia, poderia apresentar certo interesse prático. Outras organizações, como o programa das Nações Unidas para o Meio Ambiente (PNUMA), poderiam preencher este papel. De fato, podemos pensar esta entidade se transformando em Organização Mundial para o Meio Ambiente. A oportunidade de uma convenção internacional global para o meio ambiente se dá diante de regras da Organização Mundial do Comércio (OMC), que hoje reina solitária na paisagem da sociedade mundial, revelando as regras sobre as quais ela se funda.

\section{A BIOÉTICA E A ECOLOGIA PROFUNDA}

A melhor maneira de entender o que é Bioética talvez seja acompanhar a evolução de sua definição ao longo do tempo. Potter propôs, em 1998, que a Bioética está atualmente no seu terceiro estágio de desenvolvimento. Caracterizou o primeiro estágio como sendo o da Bioética Ponte, o segundo como o da Bioética Global e o terceiro, e atual, como o da Bioética Profunda.

A proposta original da palavra Bioética, feita em 1970, pelo Prof. Van Rensselaer Potter, tinha uma grande preocupação com a interação do problema ambiental às questões de saúde. Suas idéias baseavam-se nas propostas do Aldo Leopold, especialmente na sua Ética da Terra. Atualmente, esta primeira proposta é classificada por ele próprio como Bioética Ponte, especialmente pela característica interdisciplinar que foi utilizada como base de suas idéias. Esta primeira reflexão incluía um grande questionamento sobre a repercussão da visão de progresso existente na década de 1960 . O termo Bioética, ainda durante a década de 1970, devido à crescente repercussão dos avanços na área da saúde, foi sendo utilizado em um sentido mais estrito. Estas propostas foram feitas, especialmente, por Prof. Warren Reich e por LeRoy Walters, ambos vinculados ao Instituto Kennedy de Ética, da Universidade Georgetown/Washington DC, e David Roy, do Canadá. Estes autores restringiram esta reflexão apenas às questões de assistência e pesquisa em saúde. Outros autores, como Guy Durand do Canadá, também assumiram esta posição ao longo da década de 1980, mantendo a base interdisciplinar da proposta original. Esta visão restritiva foi incorporada pela base de dados Bioethicsline, que consolida a produção de conhecimento na área de Bioética. Warren Reich reiterou, em 1995 sua perspectiva para o 
termo, incorporando à sua proposta de Bioética as perspectivas interdisciplinar, pluralista e sistemática.

Em 1988, Potter reiterou as suas idéias iniciais criando a Bioética Global. O Prof. Potter entendia o termo global como sendo uma proposta abrangente, que englobasse todos os aspectos relativos ao viver, isto é, envolvia a saúde e a questão ecológica. Engelhardt defendeu a proposta de que a Bioética é uma proposta pluralista. Esta proposta também teve diferentes interpretações. Alguns autores, como Alastair Campbel e Solly Benatar entenderam o termo global não no sentido de abrangente, desde o ponto de vista interdisciplinar, mas como uma visão uniforme e homogênea em termos mundiais, enquadrando-a no processo de globalização. Ou seja, que seria estabelecido um único paradigma filosófico para o enfoque das questões morais na área da saúde, caracterizando uma nova forma de "imperialismo".

Com o objetivo de resgatar a sua reflexão original, Potter propôs, em 1998, a nova definição de Bioética Profunda, em 1998. Esta denominação foi utilizada pela primeira vez por Peter J. Whitehouse, aplicando à Bioética o conceito de Ecologia Profunda, do filósofo norueguês Arne Naess. Esta proposta abrangente e humanizadora da Bioética já vinha sendo defendida por outros autores, tal como André Comte-Sponville. Em 2001 o Programa Regional de Bioética, vinculado a Organização Pan-Americana de Saúde (OPAS) definiu bioética igualmente de forma ampla, incluíndo a vida, a saúde e o ambiente como área de reflexão. É fundamental notar como é importante para Potter manter na Bioética as características fundamentais - ampla abrangência, pluralismo, interdisciplinaridade, abertura e incorporação crítica de novos conhecimentos - em todas as suas propostas de definições.

A Ecologia Profunda, na visão de Ness, implica em realizar perguntas profundas às questões complexas que nos envolvem (CAPRA, 1998). Estabelecendo a relação com a bioética, supõe realização de autêntica "revolução espiritual" pela afirmação da dignidade intrínseca de todos os seres vivos, por meio da ativação de percepção interconexa dos fenômenos planetários e, sobretudo, na efetivação de mudanças conceituais e de comportamento (HINRICHSEN, 2010). Nos dias atuais, a compreensão ecológica mais profunda das questões humanas revela-se um desafio. Vislumbramos na sociedade atual uma crescente apropriação mercantil da causa e afirmações do movimento ecológico. Se o marketing verde vende, suas ações cosméticas escondem razões profundas da crise ambiental, estimulando o consumo predatório e perpetuando uma visão ecológica destorcida e aparentemente débil da realidade.

Assim, segundo a concepção da Ecologia Profunda e da bioética, é desafiante, uma vez que, salientamos atitudes mentais, culturais e sociais. Tais razões, nos âmbitos, científico, filosófico, social, econômico e ético nunca foram tão prementes e necessários. Pois enquanto sujeitos éticos precisamos ultrapassar a dimensão superficial do problema, indo ao encontro das transformações que a bioética e a Ecologia Profunda se propõe executar. 
Vejamos, agora, a intervenção do paradigma da Justiça no debate ecológico, seguindo ao exame da relação entre bioética, saúde e ambiente

\section{A JUSTIÇA E O MEIO AMBIENTE}

O movimento social nasceu nos Estados Unidos inspirado nas marchas em defesa dos direitos dos negros. Constatou-se que os maiores índices de poluição industrial e de presença de resíduos tóxicos estavam situados em regiões habitadas por populações afro e latino-americanas. Empresas químicas poluidoras aproveitavam-se da vulnerabilidade e baixa consciência e organização destes grupos para localizar-se nestas regiões, largando resíduos tóxicos e dejetos em cursos de água e aterros sanitários, sem encontrar oposição organizada da população.

Esse fenômeno de empurrar o ônus ambiental para as populações negras foi chamado de racismo ambiental. A constatação originou a articulação de denúncia e organização da população a não aceitar a injusta degradação do seu meio ambiente, lutando por medidas socialmente igualitárias de política ambiental. Essa movimentação formulou o princípio ético de que grupos sociais vulneráveis não devem arcar com o peso desproporcional das consequências ambientais negativas resultantes de operações comerciais, industriais ou municipais ou da execução de políticas públicas e programas federais, estaduais, locais e tribais (BULLARD, 2004).

Inspirada pelo movimento sócio-ambiental dos negros americanos foi constituída, em 2001, a Rede Brasileira de Justiça Ambiental, tendo o seu manifesto fundacional no Fórum Social de Porto Alegre de 2002. Definiu como injustiça ambiental, o mecanismo pelo qual sociedades social e economicamente desiguais destinam a maior carga dos danos ambientais às populações de baixa renda, aos grupos sociais discriminados, aos povos étnicos tradicionais, aos bairros operários, às populações marginalizadas e vulneráveis (FREITAS; PORTO, 2006).

O movimento da justiça ambiental está envolvido em conflitos sócioambientais oriundos da conformação de territórios por processos produtivos industriais, agrícolas ou mineradores, ocasionando poluição que afeta a vida e a saúde das populações circunvizinhas. Leis ambientais dos países centrais não aceitam estruturas produtivas degradantes para o ambiente, que são exportadas para países periféricos sem legislações rígidas de proteção do meio ambiente. Essas externalizações de danos ambientais, possibilitadas pela economia globalizada, não são contabilizadas como valor nos custos. É o que a economia ecológica chama de metabolismo social, processo visível na Europa, onde países importam seis vezes mais do que exportam e, contudo, têm um lucro muito superior, embora a produção não aconteça em seu território, devido ao conhecimento agregado na precificação do produto. A degradação humana e ecológica, não contabilizada no custo final, fica por conta dos países periféricos (BULLARD, 2004).

Desconhecer os efeitos colaterais destes processos macro-econômicos 
sobre o meio ambiente seria maquiar o fenômeno da degradação ambiental nos países periféricos. Os países subdesenvolvidos são responsabilizados pela degradação ambiental em seus territórios, esquecendo que ela é uma externalização de danos ambientais dos países ricos. A degradação, além de destruir ecossistemas e sua biodiversidade, afeta a saúde das populações, destruindo o meio ambiente natural e cultural base para reprodução social da vida.

As chagas ambientais manifestam-se no uso da terra pela monocultura do agronegócio exportador, espalhando desertos verdes de soja, de cana de açúcar, de eucaliptos com a correspondente exploração de trabalho sazonal em condições infra-humanas; na exploração de minerais gerando poluição e riscos para os ecossistemas e para as populações circunvizinhas; na produção de energia hidroelétrica através da construção de barragens, extinguindo biomas e expulsando pequenos agricultores de suas terras; nos conflitos sociais envolvendo o acesso ao solo urbano para moradia e na localização da poluição industrial e de resíduos tóxicos na proximidade de bairros populares (FREITAS; PORTO, 2006).

Por isso não se pode enfrentar a questão ambiental sem levar em consideração a íntima relação entre ambiente e saúde, pois os efeitos da degradação ambiental aparecem na saúde já que o ambiente configura as condições para a reprodução da vida e, para compreender essa relação, impõe-se uma visão ecológica da própria saúde humana.

\section{BIOÉTICA, SAÚDE E MEIO AMBIENTE}

A relação da saúde com o ambiente sempre foi uma preocupação humana e respondeu pela compreensão da doença como um reflexo dos miasmas presentes no ambiente. Tratava-se de uma explicação essencialmente ambiental da doença.

O progresso da biologia microbiana mudou substancialmente essa concepção. As causas não eram mais os ares fétidos, mas os micróbios que invadem o corpo do enfermo. O ambiente continua importante como reservatório de hospedeiros e vetores das patologias. A causa deixa de ser algo vago, como o miasma, identificando-se com o contágio de um micróbio. A ecologia médica estuda as relações dos fatores físicos e biológicos com a doença e a inter-relação entre o ambiente e os vetores das patologias (ÁVILAPIRES, 2000).

A revolução bacteriana trouxe grandes benefícios, contudo teve um efeito colateral negativo, o retrocesso da visão social da medicina presente na biomedicina atual. As novas doenças civilizacionais sem origem microbiana devolvem a importância ao ambiente não como reservatório, mas como um ecossistema de interdependências naturais, sociais, políticas e culturais, influenciando a saúde e a doença. Desse modo, surge a compreensão ecossistêmica da saúde, veiculada por sanitaristas brasileiros (SABROZA; LEAL, 1992; MINAYO; MIRANDA, 2000).

Revbea, Rio Grande, V. 8, N²:31-46, 2013.

revista brasileira educação ambiental 
Nessa concepção, o foco da preocupação com o ambiente não é tanto a doença, mas a saúde, agregando ao binômio "saúde-ambiente" os conceitos de sustentabilidade ecológica, qualidade de vida, justiça social, democracia e direitos humanos. Assim, o ambiente em seu sentido amplo é integrado na própria compreensão da saúde. Antes o ambiente era algo externo condicionador da doença e reduzido ao seu aspecto físico. Hoje a visão sobre a doença e a própria saúde não considera apenas fatores específicos, mas a interação entre eles. Essa concepção exige uma abordagem mais complexa da presença de riscos no ambiente.

O modelo ecossistêmico une três reflexões simultâneas: a saúde, o ambiente e, como mediação entre os dois, as condições, situações e estilos de vida dos grupos populacionais específicos. Significa conjugar saúde e ambiente, entrelaçando a sustentabilidade ecológica do ambiente natural com o desenvolvimento socioeconômico do entorno e com a qualidade de vida. A sustentabilidade e o desenvolvimento são básicos para a qualidade de vida, entendida por Minayo (2002, s/p), como:

um processo de construção de novas subjetividades pela participação em projetos de mudanças em uma ótica de desenvolvimento sustentável e de cumplicidade com as gerações futuras. Embora existam tentativas de quantificar indicadores... a definição de qualidade de vida é eminentemente qualitativa

Pois junta, "ao mesmo tempo, o sentimento de bem-estar, a visão de finitude dos meios para alcançá-lo e a disposição para a solidariedade, ampliar as possibilidades presentes e futuras". Dessa maneira, o enfoque ecossistêmico de saúde como qualidade de vida,

é como um guarda-chuva onde estão ao abrigo nossos desejos de felicidade, nossos parâmetros de direitos humanos; nosso empenho em ampliar as fronteiras dos direitos sociais e das condições de ser saudável e de promover saúde (MINAYO; MIRANDA, 2002, s/p).

Outra forma de pensar a relação entre ambiente e saúde é a teoria sobre a reprodução social da saúde proposta pelo sanitarista argentino Juan Samaja (2000; 2004), com forte influência no Brasil. Para ele, as ciências da saúde têm por objeto:

os encontros e transações entre diversos espaços de valorações e regulamentações dos problemas que a reprodução social apresenta em todas as esferas da sociabilidade humana: biossocial, sociocultural, econômicosocietal e a ecológica-política (SAMAJA, 2004, p.95-96).

Revbea, Rio Grande, V. 8, № 2:31-46, 2013. 
O objeto saúde compreende tanto as concepções e práticas sanitaristas das esferas biocomunal (reprodução biológica e ambiental), comunal-cultural (reprodução da consciência e da conduta), societária (reprodução associativa e econômica) e estatal (reprodução ecológico-política). Esse foco da saúde na reprodução social das condições de vida ultrapassa o puro espaço disciplinar da medicina, englobando epidemiologia ecológica, antropológica, sociológica, jurídica, econômica e ambientalista. Para Samaja, as condições de vida determinam as situações de saúde. Portanto, as situações de saúde devem ser estudadas na perspectiva das condições de reprodução da vida. Isso significa dizer que, se a saúde é o completo estado de bem-estar físico, psíquico, mental e social, então "ela é inseparável das condições de vida, e só se pode defini-la como controle sobre os processos de reprodução da vida social. Ou seja, a saúde constitui a própria ordem regular desse movimento reprodutivo" (SAMAJA, 2000, p.100). O ambiente identificase com as condições de vida que possibilitam a reprodução social da saúde.

O conceito integral de promoção da saúde, ultrapassando a simples compreensão de prevenção, foi explicitado pela carta de Ottawa, de 1996. Ela define promoção da saúde como a oferta de meios para a população melhorar a sua situação sanitária, exercendo maior controle sobre ela. As condições e requisitos para a saúde são: a paz, a educação, a moradia, a alimentação, a renda, o ecossistema estável, a justiça social e a equidade. As estratégias para promover a saúde incluem o estabelecimento de políticas públicas saudáveis, a criação de ambientes favoráveis, o fortalecimento de ações comunitárias, o desenvolvimento de habilidades pessoais e a reorientação dos serviços de saúde (BUSS, 2003).

Essa compreensão ampla e integral é o resultado das diversas conferências mundiais de promoção da saúde. Esse movimento parte da análise das contradições presentes nas cidades para formular propostas, pois as condições sanitárias dos grandes aglomerados urbanos atuais são os maiores desafios para a promoção da saúde. Por isso, surgiu a idéia das cidades saudáveis que procuram conjugar saúde e ambiente, comprometendo politicamente os municípios na criação das condições estruturais e comunitárias para um ambiente urbano saudável (OPAS).

\section{O MEIO AMBIENTE: RUMO À ÉTICA PARA O DESENVOLVIMENTO}

Desenvolvimento sustentável e o conceito-chave de uma série de propostas que circulam entre organismos internacionais, governos nacionais e movimentos sociais, para fazer frente a esta "crise global" em que se vê envolvido o mundo neste final de século. Ele supõe os componentes de participação e equidade e também o de crescimento econômico. Tratar-se-ia, entretanto, no plano conceitual e ético, de um crescimento econômico direcionado ao atendimento das necessidades humanas em termos de qualidade de vida e que conserve e expanda a base de recursos ambientais (CMMAD, 1987). Tal crescimento é absolutamente necessário para mitigar a 
grande pobreza que se vem intensificando na maior parte do mundo em desenvolvimento. De fato, embora o crescimento econômico não deva ser confundido com o objetivo do desenvolvimento, sua realização é condição fundamental para atingi-lo.

Como afirma a Comissão Mundial para o Meio Ambiente e o Desenvolvimento (CMMAD), a pobreza generalizada já não é inevitável. Mas, para haver um desenvolvimento sustentável, é preciso atender as necessidades básicas de todos (...), pois um mundo onde a pobreza é endêmica estará sempre sujeito a catástrofes ecológicas ou de outra natureza (CMMAD, 1987).

O documento da CMMAD insiste na necessidade do crescimento econômico, mas aponta veementemente para o princípio da equidade na distribuição dos recursos. E afirma que "tal equidade seria facilitada por sistemas políticos que assegurassem a participação efetiva dos cidadãos na tomada de decisões e por processos mais democráticos na tomada de decisões em âmbito internacional" (CMMAD, 1987).

A adoção de estilos de vida compatíveis com os recursos ecológicos do planeta - quanto ao consumo de energia, principalmente nas sociedades desenvolvidas, por exemplo - , bem como mudanças na forma de exploração dos recursos naturais, na orientação dos investimentos, nos rumos do desenvolvimento tecnológico e nas relações internacionais, são posturas e compromissos indispensáveis a serem assumidos em escala planetária pelos organismos internacionais e governos nacionais e difundidos para o debate e adoção, no que couber, pela população.

O marco ético para um desenvolvimento adequado está na necessidade de que ele ocorra como um processo participativo, equitativo e sustentável (CEPAL, 1991). Participativo porque deve assegurar o concurso de todos em sua construção; equitativo porque seus beneficias devem universalizar-se em função das necessidades; e sustentável por que, na sua realização, não deve comprometer a possibilidade de uma vida adequada para as futuras gerações sobre a Terra. Ou seja, um novo tipo de desenvolvimento capaz de manter o progresso humano não apenas em alguns lugares e por alguns anos, mas em todo o planeta e por muito tempo (CMMAD, 1987).

Igualmente, o conceito de saúde articulado com este modelo, precisa ser diferente do atual, contemplando outras dimensões da vida humana, inclusive suas interações com um ambiente protegido e não apenas dominado pelas relações econômicas. Uma nova ética passa pela valorização da informação, considerando o indivíduo não apenas como receptor, mas garantindo seu acesso ao conhecimento acumulado pela sociedade. A informação é importante que se ressalte, dirigida para o desenvolvimento de estratégias de produção, e não para definir padrões de consumo!

Uma nova ética pressupõe também um mundo integrado, mas que culturais e ambientais. Uma nova ética implica em compromisso com a 
democracia, significando este conceito um novo modelo de relação entre os indivíduos e, destes, com o Estado, além de uma outra ordem internacional (RODRIGUEZ, 1991).

Para que a nova ética não seja apenas uma utopia, mas o fundamento para um novo modelo de desenvolvimento, é indispensável a superação do nível de miséria e da falta de instrução de grande parte da população, o que impede sua inserção efetiva no processo econômico e político e, portanto, o controle sobre suas condições concretas de existência, pressuposto da cidadania.

Os ajustes inevitáveis na conjuntura atual, para as crises políticas, econômicas e ambientais, por sua vez, não podem resultar em um estreitamento das possibilidades de transformações estruturais, comprometendo o futuro, mas sim tem de considerar a necessidade e as possibilidades de fundação de uma nova ordem mais justa e equânime, baseada nos princípios da solidariedade entre nações, povos e grupos sociais.

Não é suficiente, portanto, propiciar respostas tecnológicas ou modificar os modelos de crescimento econômico vigentes sem revisar simultaneamente os valores sobre os quais sustentará a nova ordem internacional necessária.

Desenvolvimento com equidade, aproveitamento racional dos recursos naturais baseado em conceitos de sustentabilidade, solidariedade universal expressa em uma nova concepção de cooperação, transferência rápida de conhecimentos e processos de revalorização da vida em seu componente qualitativo parecem constituir requisitas e urgências do presente.

Fundar uma nova ética do desenvolvimento, num contexto onde a questão ambiental seja uma causa planetária, exige uma nova postura das nações desenvolvidas para com as nações em desenvolvimento e, destas, um maior compromisso com a equidade social (MÉDICI E AGUIAR, 1992).

De fato, a maioria dos documentos insiste na necessidade de se estabelecer uma cooperação internacional efetiva para lidar com a interdependência ecológica e econômica. Assim, uma mudança de orientação nos órgãos internacionais que tratam de empréstimos para o desenvolvimento, regulamentação do comércio, desenvolvimento agrícola etc. - que pouco consideram a importância dos efeitos de suas atividades sobre o meio ambiente - é fator essencial a ser logrado na consertação multilateral em torno da questão ambiental. A facilitação e, mesmo, o estímulo na transferência de tecnologias industriais limpas (ao invés da sucata industrial com que brindam o Terceiro Mundo as multinacionais) e de tecnologias adequadas para a proteção e a recuperação ambientais são acordos mínimos a serem celebrados na regulação das relações econômicas interpaíses, com a supervisão dos organismos internacionais. Caso contrário, estaremos trafegando na vã avenida da retórica que com grande frequência preside os foros internacionais.

Da mesma forma, o tratamento adequado para à divida externa dos países do Terceiro Mundo, que se transformaram na década de $80 \mathrm{em}$ 
exportadores líquidos de capital, com as tremendas consequências humanas e ambientais, será possivelmente a medida de maior impacto que se logrará no terreno ecológico, em nível planetário. A questão é saber a serviço de quem estão os organismos multilaterais e internacionais que tratam da questão da divida e qual o compromisso das lideranças do Primeiro Mundo com a proteção ambiental do planeta: retórica ou efetiva?

Seguindo a trilha de nossa discussão, analisaremos agora, a contribuição da Ética da Libertação à questão ecológica.

\section{A ÉTICA DA LIBERTAÇÃO E A QUESTÃo ECOLÓGICA}

A Ética da Libertação de Leonardo Boff (1996) possui inegável contribuição à questão ambiental. Para ele, a ética da libertação e o discurso ecológico têm algo em comum: partem de duas chagas que sangram. A primeira é a chaga da pobreza, e a segunda, a da agressão da terra ameaçada pela depredação realizada a partir do desenvolvimento montado pelas sociedades contemporâneas. Também ambas visam à libertação: uma, dos pobres, a partir deles mesmos como sujeitos históricos organizados, que assumem a sua luta; a outra, a da Terra, mediante uma nova aliança do ser humano com ele e com o tipo de desenvolvimento que respeite os diferentes ecossistemas e uma boa qualidade de vida dos seus cidadãos (BOFF, 1996).

Dito isto, é necessário frisar a importância na discussão às três ecologias que o autor se utiliza no seu debate: a ecologia ambiental, condizente para com as injustiças com a natureza, a social, na forma de lutas para com causa ecológica, que interfiram na vida das pessoas, e a ecologia mental, que traz uma reflexão acerca da conscientização do homem para com a questão (GUATARRI, 2001).

Assim, uma ética da libertação deve assumir o discurso ecológico para uma nova cosmologia, ou seja, uma visão que entende a Terra como um grande organismo vivo e articulado com o universo inteiro em cosmogênese. Pois os ser humano foi criado para o universo e não vice-versa, para realizar uma etapa mais alta e complexa da evolução universal.

Pensa-se que não apenas os pobres e oprimidos dever ser libertados, mas todos os seres humanos que habitam a Terra e que são excluídos por um modelo de vivência que escraviza o valor de cada pessoa e não exalta dignamente. No entendimento dele,

O desafio será conseguir que os seres humanos se entendam como uma grande família terrenal junto com as outras espécies e que redescubram seu caminho de volta à comunidades dos seres viventes, à comunidade planetária e cósmica (BOFF, 1996, p.176). 
Essa forma de pensar a questão ecológica não quer apenas meio ambiente, e sim o ambiente inteiro. Pois o ser humano e a sociedade dentro da natureza são partes diferentes dentro dela. Preocupar-se, não apenas com a beleza das cidades, das praças, mas priorizar o saneamento básico, uma boa rede de escolar, de serviços públicos, de assistência social mais digna ao ser humano são tarefas urgentes (BOFF, 1999). A injustiça social significa violência ao ser mais complexo e singular, que é a pessoa humana, e ela é parte integrante dessa natureza. A ecologia social propõe um desenvolvimento sustentável que atenda às necessidades das pessoas, sem prejudicar 0 planeta, e visa melhorar as condições futuras enquanto humanidade.

No imaginário da sociedade moderna, o desenvolvimento é movido dentro de dois polos: o infinito dos recursos naturais e o infinito do desenvolvimento rumo ao futuro. Mas sendo assim, os recursos não são ilimitados na sua maioria; estão sendo postos em degradação e pode tornar-se incertos no futuro da história. As sociedades sempre organizam suas relações com o meio, no sentido de garantir a produção e reprodução da vida. Definem a relação entre o campo e cidade, como se faz urbanização, como se estabelecem relações com o privado e público, como se evita a violência e, como tal, que forma de ciência e técnica pode garantir a qualidade de vida (GUATARRI, 2001). Carecemos de uma sociedade sustentável que encontre 0 desenvolvimento viável para as necessidades de todos. Aqui estão os limites para uma ecologia mais humana e social no quadro atual.

Consequentemente, o desafio ecológico é muito complexo. A mesma situação do desenvolvimento está inclusa nesse desafio, pois o mesmo diz respeito à reta utilização dos recursos naturais para o bem-estar do homem. Assim, é urgente criar novos modelos de desenvolvimento, a partir de novos modos de produção-consumo, que respeitem o meio ambiente e reorientem a pesquisa científica, para que se desenvolvam um melhor relacionamento entre homem e natureza (COSTA, 2004). A Bioética contribui nessa mudança, na medida em que, fiel à perspectiva integradora da realidade do ser humano, for capaz de realçar a responsabilidade humana, visto na união entre homem e a natureza. Pois a reflexão bioética com seu discernimento pode contribuir à sociedade a se posicionar de modo mais crítico e construtivo com a totalidade do meio ambiente, na forma de responder ao desafio ambiental, dentro de uma perspectiva integral de homem.

No âmbito estrutural aparece de maneira relevante e indispensável quanto a dimensão "revolucionária"; a situação de degradação da humanidade frente ao ambiente em que habitamos, mas também problemática perante as desigualdades sociais geradas pelo sistema-mundo e no mau uso dos recursos que o Planeta dispõe. 


\section{CONSIDERAÇÕES FINAIS}

Dentro do debate travado por nós, partindo das relações entre a bioética e a questão ambiental, em face de uma ética do desenvolvimento, podemos traçar algumas pistas. A crise ecológica, com suas múltiplas ramificações, é resultado do modelo de desenvolvimento levada pela Civilização industrial em conexão com uma determinada autoconsciência do homem moderno. Trata-se de caracterizá-la como antropocêntrica ao extremo, que tem levado o homem e a sociedade a considerarem-se senhores absoluta da natureza. Não podemos ignorar que na ciência atual se impõe, uma visão unitária de universo, existindo continuidade e solidariedade desde as partículas mais elementares presentes na origem da matéria até os mais complexos seres vivos, especialmente o homem. Por sua vez, o discurso ético ambiental tem procurado mostrar que a fé cega no progresso científico constituiu umas das premissas básicas que teria feito possível, no Ocidente europeu, o surgimento da ciência e o domínio arbitrário da natureza pelo homem.

Sendo assim, não é mais possível tratar da libertação do ser humano independente do cosmos. Isto é válido, tanto no nível cosmológico, como no nível mais abrangente da dimensão sociopolítica! Tal problemática ecológica afeta os países da América latina, uma vez que trata de um desenvolvimento que concentra a riqueza em poucas mãos, à custa de uma lógica de exclusão da grande maioria da população, e que, outra parte, se tem revelado por vários séculos geradora de desigualdades sociais em prol de um status quo.

Logo, o clamor dos oprimidos constitui um forte desafio para a consciência bioética e ambiental de que é necessário olhar o mundo por outro ângulo e um novo paradigma que possibilite novas interpretações da realidade social. Revolução estrutural no campo ecológico deve estar articulada mediante uma relação de inclusão com a devida contribuição de uma bioética política e vice-versa.

\section{REFERÊNCIAS}

BOFF, L. Ecologia: grito da Terra, grito dos pobres. 2 ed. São Paulo: Ática, 1996.

BOFF, L. Ética da vida. Brasília: Letraviva, 1999.

CMMAD/Comissão Mundial sobre Meio Ambiente e Desenvolvimento das Nações Unidas. Nosso Futuro Comum. 1987.

CASTELLS, M. A Questão urbana. Rio de Janeiro: Paz e Terra, 1975.

BULLARD, R. Enfrentando o racismo ambiental no século XXI. In: ACSELRAD, H.; HERCULANO, S.; PÁDUA. J.A. (Orgs.). Justiça ambiental e cidadania. Rio de Janeiro: Relume Dumará, 2004, p. 41-66.

BUSS, P. M. Uma introdução ao conceito de Promoção da Saúde. In: CZERESNIA, D.; FREITAS, CM. (org). Promoção da saúde: conceitos, reflexões, tendências. Rio de Janeiro: editora Fiocruz, 2003.

Revbea, Rio Grande, V. 8, № 2:31-46, 2013. 
BUSS, P. Ética e Ambiente. Disponível em:

$<$ http://www.portalmedico.org.br/include/biblioteca virtual/des etic/6.htm> Acesso em: 18/01/2011.

CAPRA, F. A Teia da vida. São Paulo: Cultrix, 1998.

CEPAL. Comissão Econômica para América Latina e Caribe. El desarrollo sustentable: transformación produtiva, equidad y medio ambiente. Santiago de Chile, Doc. LC/G 1986, 1991.

COSTA, C.A.S. Teologia: serviço evangélico a ecologia. Teocomunicação, Porto Alegre, v. 34, n. 144, p. 391-402, jun. 2004.

DUVOISIN, I. A necessidade de uma visão sistêmica para a educação ambiental: conflitos entre o velho e no novo paradigma. In: RUSCHEINSKY, A. (Org.). Educação Ambiental: abordagens múltiplas. Porto Alegre: Artmed, 2002. p. 91-104

FREITAS, C.M.; PORTO, M.F. Saúde, Ambiente e Sustentabilidade. Rio de janeiro: Ed. Fiocruz, 2006.

FREITAS, C.M. (Orgs.). Promoção da Saúde: conceitos, reflexões, tendências. Rio de Janeiro: Ed. Fiocruz, 2003, p. 15-38.

GOLDIM. J.R. A evolução da Bioética. Disponível em:

$<$ http://www.ufrgs.br/bioetica/bioetev.htm>. Acesso em: 18/1/2011.

GUATARRI, F. As Três ecologias. 11 ed. Campinas: Papirus, 2001.

HINRICHSEN, L.E. Ética ambiental. Cadernos da Estef, Porto Alegre, n. 44, dez. 2010/1. p. 85-94.

JUNGES, J.E. Bioética e meio ambiente no Brasil: uma abordagem hermenêutica, 2007.

ÁVILA-PIRES, F.D. Princípios de Ecologia médica. Florianópolis: UFSC, 2000.

MAZAUDOUX, O. Política Internacional, Direito ambiental e questões institucionais. In: MACEDO, C. (Coord.). Políticas públicas ambientais. São Paulo: Revista dos Tribunais, 2009. p. xxxxx.

MÉDICI, A.C.; AGUIAR, M.A.S. Desenvolvimento sem Ética. Políticas Governamentais. VIII (80): 3944, mai/jun, 1992.

MINAYO, M.C.; MIRANDA, A.C. (Orgs.). Saúde e Ambiente sustentável: estreitando nós. Rio de Janeiro: Fiocruz - Abrasco, 2002.

MINAYO, M.C. Enfoque ecossistêmico de saúde e qualidade de vida. In: MINAYO M.C., MIRANDA, A.C. (orgs.) Saúde e Ambiente sustentável: estreitando nós. Rio de Janeiro: Fiocruz - Abrasco, 2002, p. 174

MORAN, E. Introdução ao pensamento complexo. Porto Alegre: Sulina, 2007. 
MOSER, A. Ecologia: desafio teológico e ético. Revista Vozes. Petrópolis, LXXIII (1), p.46, jan.-fev. 1979.

OLIVEIRA, F. Bíblia, Mito, Ciência e Literatura: abordagem interdisciplinar da História das Origens em Gênesis 1-11. Pelotas: EDUCAT, 1998.

RODRIGUES, R.H.; SABROZA, P.C.; LEAL, M.C; BUSSA, P.M. A ética do desenvolvimento e as relações com saúde e meio ambiente, LEAL, M.C.; SABROSA, P.C.; RODRIGUES, R.H.; BUSS, P.M. (Orgs) Saúde, Ambiente e Desenvolvimento. Volume I. Uma análise Interdisciplinar. Hucitec-ABRASCO, Rio de Janeiro, 1992.

LEAL, M.C.; SABROSA, P.C.; RODRIGUES, R.H.; BUSS, P.M. (Orgs) Saúde, Ambiente e Desenvolvimento. Volume I. Uma análise Interdisciplinar. Hucitec-ABRASCO, Rio de Janeiro, 1992.

SAMAJA, J. A reprodução social e a saúde: elementos teóricos e metodológicos sobre a questão das "relações" entre saúde e condições de vida. Salvador: Casa da Saúde, 2000.

SAMAJA, J. Epistemología de la salud: Reproducción social, subjetividad y transdisciplina. Buenos Aires: Lugar Editorial, 2004.

ORGANIZAÇÃO PAN-AMERICANA DA SAÚDE, Municípios e Comunidades saudáveis. Guia dos prefeitos para promover a qualidade de vida. Disponível em <http://www.opas.org.br/sistema/arquivos/Mun SAUD.pdf.>. Acessado em 25 de janeiro de 2014.

ANDRADE, L.O.M; BARRETO, I.C.H.C. Promoção da saúde e Cidades / Municípios Saudáveis: propostas de articulação entre saúde e meio ambiente. In: MINAYO, M.C.; MIRANDA, A.C. (Orgs.). Saúde e Ambiente sustentável: estreitando nós. Rio de Janeiro: Fiocruz - Abrasco, 2002, p. 151-171. 